\title{
Analysis of Determinants of Cassava Production and Profitability in Akpabuyo Local Government Area of Cross River State, Nigeria
}

\author{
Kingsley Okoi Itam ${ }^{1}$, Eucharia Agom Ajah ${ }^{1} \&$ Emmanuel Edet Agbachom ${ }^{1}$ \\ ${ }^{1}$ Department of Agricultural Economics \& Extension, University of Calabar, Calabar, Nigeria \\ Correspondence: Kingsley Okoi Itam, Department of Agricultural Economics \& Extension, University of \\ Calabar, Calabar, Nigeria. E-mail: itamkingsley@yahoo.com
}

Received: August 29, 2014

Accepted: September 23, 2014

Online Published: November 25, 2014

doi:10.5539/ibr.v7n12p128

URL: http://dx.doi.org/10.5539/ibr.v7n12p128

\begin{abstract}
The study examined the determinants and profitability of cassava production in Akpabuyo, Cross River State. A multistage sample procedure was used to select eighty (80) farmers and data were collected with structured questionnaire. Data were analyzed using descriptive statistics, gross margin and ordinary least square (OLS) criterion. Analysis shows that cassava production was dominated by females (67.5 percent) in the study area. The mean age (47.85) shows that farmers were in the active labour force with mostly small farm sizes (0.98ha). The profitability analysis also shows per hectare gross margin of $\$ 9,520.66$ and the cost $\$ 7,001.94$, implying that cassava production is profitable. The results further reveals that farm size, value of land, gender, age, educational level and farming experience influenced output positively, while value of cassava cuttings, labour and family size had negative influence on cassava output. However, the test of significance shows that cassava cuttings, labour, education and experience exerted greater influence on cassava output, implying that a change in any one of these variables resulted to a significant change in output. One of the most serious problems encountered by cassava farmers in the study area was high cost of inputs, while lack of implements constituted the least problem. Therefore, it is recommended that concerted effort should be made towards the implementation of policies that will enhance farmers output.
\end{abstract}

Keywords: Cassava, determinants, ordinary least square, production, profitability

\section{Introduction}

Agriculture has been the major driver of the Nigerian economy over the years, providing employment for about 70 percent of the population and accounting for more than one third of total gross domestic product (GNP) and labour force (FAO, 2005; World Bank, 2003). The sector made a remarkable contribution to the gross domestic product with its contribution rising from 36.5 percent to 41.48 percent in 2009 and 44.40 percent in 2011 . However, current contribution of agriculture is 21.91 percent due to rebasing of the GDP (Atuanya \& Augie, 2014).

The position of agriculture as a leading sector in the Nigerian economy is currently being threatened by other subsectors; construction, manufacturing and entertainment. Therefore, there is urgent need to address the transformation policy in the agricultural sector.

Agricultural activities provide the basic source of livelihood upon which rural life depends, providing food and income for sustenance. The major crops cultivated include cassava, yam, rice, oil palm, cocoyam, cocoa, beans, groundnut, maize, etc.

Cassava is a well-known root crop which derives its origin from South and Central America and was introduced into Africa in the $16^{\text {th }}$ century (ICTA 2001). It is a major staple to most Nigerians, as its products and by products are extensively used. Abang and Agom (2004), noted that the consumption of cassava cuts across all parts of the country. The crop can easily adapt to climate and soil conditions, hence its ability to grow and be available all year round. Cassava yields according to IITA, are above 22.0 tons per hectare even on poor soils. This feature gives it superior advantage over other tuber crops like yams, cocoyam and potato. Cassava products are generally accepted by all classes of Nigerians, and this makes it attractive to farmers. Cross River State is one of the leading producers of the crop in the South South region of Nigeria. There is a great potential both for export and domestic consumption for cassava. Its usefulness as a wide spectrum, range from the leaves to the roots 
which are mostly used for animal feeds and food processing. There is also renewed effort by the present administration to make cassava a revenue generating crop. This has encouraged investment in cassava research, which has been hampered by years of research into better known staples such as wheat, rice and maize.

Therefore, this study is to complement the various efforts of research in improving cassava production in Nigeria. The major objective is to evaluate the factors that determine output and profitability of cassava production. Specifically, the study examines the determinants of output of cassava production. It analyzes the cost and returns in cassava production, identifies the constraints of cassava production and suggests ways for improvement to boost productivity.

\subsection{Conceptual Framework}

Productivity and profitability are some of the basic concepts in economics of agricultural production. Agricultural productivity is synonymous with resource productivity which is the ratio of total output to the resource or inputs used. Output is usually measured as the market value of final output, which excludes intermediate products. This output value may be compared to many different types of inputs such as labour and land (yield).The importance of agricultural productivity cannot be overemphasized, aside from providing more food, increasing the productivity of farms affects a nation's prospects for growth and competitiveness on the agricultural market, income distribution and savings, and labour migration. Also increases in agricultural productivity lead to agricultural growth and can help to alleviate poverty in poor and developing countries, where agriculture often employs the greatest portion of the population.

Olujenyo (2010), noted that productivity measurement involves the use of basic concepts such as Average product (AP), Marginal Product (MP), Marginal Rate of Substitution (MRS), Elasticity of production (EP) and Returns to scale (RTS).The three stages of production are studied using these concepts. The production function consists of different functional forms. These include the Cobb Douglas which is often used by researchers due to its simplicity and flexibility, linear, quadratic polynomials and square root polynomials. Others are semi- log and exponential functional forms.

On the other hand, profitability is a measure of the relationship between the levels of profits earned during an accounting period and the level of resources committed to earn those profits (Barry et al, 1983). It relates the level of profits to the volume of sales or to the efficiency with which various types of resources are managed. Thus, profit maximization is achieved by maximizing output from a given resource or minimizing the resources required for a given output. Profitability is influenced by the margins between costs and returns per unit of production and the number of units sold, hence it is closely tied to efficiency and scale.

Several studies have been carried out on the determinants and profitability of agricultural production in Nigeria. Most of these studies concentrated on cereals and very few on tuber crops. Using ordinary least square (OLS) criterion, Olujenyo in the study of determinants of agricultural production reported that age, education, labour and cost of non-labour inputs were positively related to output with labour input having significant influence on output, while farm size, years of experience and sex showed inverse relationship with output. The study further revealed that maize farming was profitable. Mohammed (2011) and Oyinbo et al (2011) in their study of Economics of rainfed and irrigated rice production, and assessment of the profitability of smallscale cassava production respectively, found that labour, farm size, family size, fertilizer use, education level, and market variables were the significant determinants of production and profitability. The authors employed the use of gross margin in their analysis.

Imoudu (1992), also showed that farm size and labour were the significant determinants of maize output and profitability in Ondo State. Abdullahi (2012), in the study of comparative economic analysis of rice production found that farm size and fertilizer use were the significant determinants of output of rice.

\section{Materials and Methods}

\subsection{Study Area}

Akpabuyo Local Government Area was created out of Odukpani Local Government Area in 1997 and became the $14^{\text {th }}$ and $58^{\text {th }}$ Local Government Area in Cross River State and Nigeria respectively. Akpabuyo has a population of over 271,325 people (NPC, 2006). It is located in the Calabar Agricultural zone with its headquarters at Ikot Nkanda. It is also located between latitude $4^{0} 5^{\prime \prime} \mathrm{N}$ and $5^{0} 4^{\prime \prime} \mathrm{S}$ and longitude $8^{0} 25^{\prime \prime} \mathrm{W}$ and $8^{0} 32$ " East. It is within the vegetative belt of southern Nigeria and shores of the Atlantic coastline with Bakassi to the East and the Republic of Cameron to the West. There are twenty-eight (28) villages in Akpabuyo and the primary economic activities are farming and fishing. Hence, it is known as the food basket of Cross River State. The major agricultural products are cassava, cocoyam, kola nut, oil palm, maize, etc. Other economic activities are 
palm wine tapping, processing of wild palm fruits, tailoring, welding, trading, processing of cassava into garri and $f u f u$ for sale. Natural resources also abound in Akpabuyo. The area is rich in mineral deposits such as petroleum, gold, limestone, sand, salt, etc, all of which are available in commercial quantities for prospective explorers.

\subsubsection{Sampling Procedure and Sample Size}

The multistage sampling technique was employed in this study. The first stage was the purposive selection of Akpabuyo as the major farming area in the Calabar agricultural zone. In the second stage, sixteen (16) villages were randomly selected from twenty-eight (28). Then, five (5) farmers were selected from each of the sixteen villages making a total of eighty (80) farmers. Data were collected with the use of structured questionnaires to obtain information on farmers' socio-economic variables, farm size (ha), cost of inputs, output and value of output for the 2013 farming season.

\subsection{Analytical Techniques}

Data collected were analyzed using descriptive statistics, gross margin analysis and quantitative methods. Descriptive statistics such as means, percentage count and standard deviation were used to analyze farmer's socio-economic characteristics and constraints to cassava production. Gross margin was used to analyze the profitability level, while the ordinary least square (OLS) regression analysis was carried out to determine the effect of the variables in cassava production.

\subsection{Model Specification}

The production function analysis was used in four functional forms from which the lead equation was chosen on the basis of the values of the coefficient of multiple determination $\left(\mathrm{R}^{2}\right)$ as well as the signs and significance of the regression parameters. This was stated explicitly as;

$$
Y=f\left(X_{1}, X_{2}, X_{3}, X_{4}, X_{5}, X_{6}, X_{7} X_{8}, X_{9}, u\right)
$$

Where;

$\mathrm{Y}=$ Total output of cassava $(\mathrm{Kg})$

$\mathrm{X}_{1}=$ farm size (ha)

$\mathrm{X}_{2}=$ value of land

$\mathrm{X}_{3}=$ value of cassava cuttings (bundles)

$\mathrm{X}_{4}=$ Labour in man days

$\mathrm{X}_{5}=$ Gender $($ male $=1$, female $=0)$

$\mathrm{X}_{6}=$ Age

$\mathrm{X}_{7}=$ Educational level

$\mathrm{X}_{8}=$ Farming experience

$\mathrm{X}_{9}=$ Family size

$\mathrm{U}=$ Error term

Profitability was estimated using gross margin analysis, which is the difference between total revenue (TR) and the total variable cost (TVC). This is because fixed cost was negligible in cassava production. It is given as;

$$
G M=T R-T V C
$$

Where;

$\mathrm{GM}=$ Gross margin

$\mathrm{TR}=$ Total Revenue $=\mathrm{P} . \mathrm{Q}(\mathrm{P}=$ Price, $\mathrm{Q}=\mathrm{Quantity})$

TVC $=$ Total variable cost

\section{Results and Discussion}

\subsection{Socio-Economic Characteristics of Sampled Cassava Farmers}

Table 1 shows that cassava production was dominated by the female population as about 68 percent of them owned cassava farms. This is because cassava production is often regarded as women business in most communities in Nigeria. This is in agreement with Abang and Agom (2004), who also noted that the female population was more involved in cassava production. The age groups of the farmers were mostly between 21 and 
50 years representing about 98 percent with a mean of about 48 years, implying that most of the farmers were in the active labour force and output is expected to increase.

The educational status of the farmers, shows that majority of the farmers, about 83 percent had one form of education or the other with a mean of 5.34. Majority (52.5 percent) had secondary education while $10,18.75$ and 1.25 percent had primary, vocational and tertiary education respectively. This means that farmers will be more receptive to farm innovations. Abam (2009), reported a similar result. Farmers with no formal education constituted 17.5 percent of the population. Furthermore, the largest group had between seven to eight members in their household and this constituted about 44 percent of the sampled population. The mean family size was about 5, confirming Effiong (2005), who reported that a relatively large household size enhances the availability of family labour which reduces constraint on labour cost in agricultural production. A very high proportion (96 percent) of the farmers had between 5 and above twenty (20) years of experience in cassava production. The mean farming experience was about 17 years. This implies that farmers will experience increased output given the number of years they have spent farming, they are expected to have gained enough knowledge. Nwaru (2004), noted that farmers sometimes count more on their experiences than educational attainment in order to increase their productivity. Also farmers kept small farm sizes ranging between 0.1 to 0.8 ha with a mean of 0.98 ha. Farmers with farm sizes between 0.1 to 0.5 ha constituted the majority ( 65 percent).

Table 1. Socio-economic characteristics of cassava farmers

\begin{tabular}{|c|c|c|}
\hline Variable & Frequency & Percentage \\
\hline \multicolumn{3}{|l|}{ Gender } \\
\hline Male & 26 & 32.50 \\
\hline Female & 54 & 67.50 \\
\hline Total & 80 & 100 \\
\hline \multicolumn{3}{|l|}{ Age } \\
\hline $21-30$ & 16 & 20 \\
\hline $31-40$ & 20 & 25 \\
\hline $41-50$ & 42 & 52.50 \\
\hline$>50$ & 2 & 2.50 \\
\hline Total & 80 & 100 \\
\hline Mean & 47.85(7.109) & \\
\hline \multicolumn{3}{|l|}{ Educational status } \\
\hline No formal education & 14 & 17.5 \\
\hline Primary education & 8 & 10 \\
\hline Secondary education & 42 & 52.5 \\
\hline Vocational education & 15 & 18.75 \\
\hline Tertiary education & 1 & 1.25 \\
\hline Total & 80 & 100 \\
\hline Mean & $5.34(2.294)$ & \\
\hline \multicolumn{3}{|l|}{ Family size } \\
\hline $1-3$ & 14 & 17.5 \\
\hline $4-6$ & 31 & 38.75 \\
\hline $7-8$ & 35 & 43.75 \\
\hline Total & 80 & 100 \\
\hline Mean & $5.475(1.691)$ & \\
\hline
\end{tabular}




\begin{tabular}{lcc}
\hline Farming experience & \multicolumn{2}{c}{} \\
$\leq 5$ & $\mathbf{3}$ & 3.75 \\
$6-10$ & $\mathbf{1 2}$ & 15 \\
$11-20$ & $\mathbf{4 5}$ & 56.25 \\
$>21$ & $\mathbf{2 0}$ & 25 \\
Total & $\mathbf{8 0}$ & 100 \\
Mean & $\mathbf{1 7 . 4 ( 5 . 6 6 2 )}$ & \\
\hline Farm size & & 65 \\
$\leq 0.5$ & 52 & 26.25 \\
$0.6-0.8$ & 21 & 8.75 \\
$>0.8$ & 7 & 100 \\
Total & $\mathbf{8 0}$ & \\
Mean & $\mathbf{0 . 9 8}(\mathbf{0 . 3 3 2})$ & \\
\hline
\end{tabular}

Source: Field survey 2013.

Note: Values in parentheses are standard deviations.

\subsection{Results of Regression Analysis}

Four functional forms namely linear, semi-log, double log and exponential forms were estimated (Table 2). The double $\log$ function was chosen as the lead equation. The choice of the double log function was predicated on its confirmation of a priori expectation in terms of sign magnitude of the coefficient, the number of significant variables and the coefficient of multiple determination $\left(\mathrm{R}^{2}\right)$. The equation is given as follows;

$$
\begin{aligned}
& Y=6.855+0.010 X 1+0.184 X 2-0.230 X 3-0.289 X 4+0.165 X 5+0.533 X 6+0.004 X 7+0.196 X 8-0.088 X 9 \\
& \begin{array}{llllll}
(0.119) \quad(1.593) \quad(-1.798) & (-2.173) \quad(1.381) \quad(4.120) \quad(0.053)
\end{array}
\end{aligned}
$$

The results showed that a relationship existed between total output and the explanatory variables included in the model. The coefficients of farm size, value of land, gender and educational attainment and farming experience had positive signs, implying that these variables had a direct relationship with cassava output. As more of these variables are employed, there will be an increase in total output of cassava. This agrees with a prior except age. The a priori expectation of the sign of coefficient of age should be negative. The positive sign could be attributed to the fact that farmers are gaining more experience as they grow older. On the other hand, the coefficients of cassava cuttings, labour and family size had negative signs, implying inverse relationship with output. Again, this is unexpected. The other three models (linear, semi-log and exponential) did not produce better results. The negative relationship between output and cassava cuttings could be due to depletion of soil fertility and continuous use of obsolete farming techniques, while that of labour could be attributable to its overuse which resulted in decrease output.

However, the test of significance shows that value of cassava cuttings, labour, education and experience were statistically significant at $10,5,1$ and 5 percent respectively. The estimated $\mathrm{R}^{2}$ shows that 63 percent of variations in total output of cassava were explained by the explanatory variables with the remaining 37 percent due to random error $(\mathrm{U})$ in the model. 
Table 2. Result of estimated linear, semi-log, double-log and exponential production function for cassava production

\begin{tabular}{|c|c|c|c|c|c|c|c|c|c|c|c|c|c|}
\hline $\begin{array}{c}\text { Functional } \\
\text { forms }\end{array}$ & Constant & $\mathrm{X} 1$ & $\mathrm{X} 2$ & $\mathrm{X} 3$ & $\mathrm{X} 4$ & $\mathrm{X} 5$ & X6 & $\mathrm{X} 7$ & $\mathrm{X} 8$ & $\mathbf{X}_{9}$ & $\mathrm{R} 2$ & $\begin{array}{c}\text { Adjusted } \\
\text { R2 }\end{array}$ & Fcal \\
\hline Linear & $\begin{array}{c}1520.149 \\
(2.232)\end{array}$ & $\begin{array}{c}-0.024 \\
(-0.305)\end{array}$ & $\begin{array}{c}0.201 \\
(1.723)\end{array}$ & $\begin{array}{c}-0.33 \\
(-3.499) * * *\end{array}$ & $\begin{array}{c}-0.32 \\
(-2.363)^{*}\end{array}$ & $\begin{array}{c}0.207 \\
(1.674)^{*}\end{array}$ & $\begin{array}{c}0.478 \\
(4.027)^{* * *}\end{array}$ & $\begin{array}{c}0.028 \\
(0.357)\end{array}$ & $\begin{array}{c}0.129 \\
(1.503)\end{array}$ & $\begin{array}{c}0.053 \\
(0.594)\end{array}$ & 0.589 & 0.534 & 11.061 \\
\hline Semi-log & $\begin{array}{c}7.026 \\
(19.890)\end{array}$ & $\begin{array}{c}0.013 \\
(0.164)\end{array}$ & $\begin{array}{c}0.0202 \\
(1.749) *\end{array}$ & $\begin{array}{c}-0.260 \\
(-2.697)^{* * *}\end{array}$ & $\begin{array}{c}-0.302 \\
(2.240)^{* *}\end{array}$ & $\begin{array}{l}0.2138 \\
(1.734)\end{array}$ & $\begin{array}{c}0.511 \\
(4.341) * * *\end{array}$ & $\begin{array}{c}0.078 \\
(0.994)\end{array}$ & $\begin{array}{c}0.156 \\
(1.833)\end{array}$ & $\begin{array}{l}-0.083 \\
(0.936)\end{array}$ & 0.594 & 0.541 & 11.358 \\
\hline Double-log & $\begin{array}{c}6.855 \\
(4.371)\end{array}$ & $\begin{array}{c}0.010 \\
(0.119)\end{array}$ & $\begin{array}{c}0.184 \\
(1.593)\end{array}$ & $\begin{array}{c}-0.230 \\
(-1.798) *\end{array}$ & $\begin{array}{c}-0.289 \\
(2.173) * *\end{array}$ & $\begin{array}{c}0.165 \\
(1.381)\end{array}$ & $\begin{array}{c}0.533 \\
(4.120) * * *\end{array}$ & $\begin{array}{c}0.004 \\
(0.053)\end{array}$ & $\begin{array}{c}0.196 \\
(2.389)^{* *}\end{array}$ & $\begin{array}{c}-0.088 \\
(-1.039)\end{array}$ & 0.631 & 0.582 & 13.084 \\
\hline Exponential & $\begin{array}{c}2441.955 \\
(0.773)\end{array}$ & $\begin{array}{c}-0.051 \\
(-0.599)\end{array}$ & $\begin{array}{c}0.173 \\
(1.423)\end{array}$ & $\begin{array}{c}-0.361 \\
(-2.242)^{* *}\end{array}$ & $\begin{array}{c}-0.299 \\
(-2.135)^{* *}\end{array}$ & $\begin{array}{c}0.161 \\
(1.285)\end{array}$ & $\begin{array}{c}0.473 \\
(3.475) * * *\end{array}$ & $\begin{array}{c}-0.055 \\
(-0.678)\end{array}$ & $\begin{array}{c}0.196 \\
(2.225) * *\end{array}$ & $\begin{array}{c}-0.069 \\
(-0.777)\end{array}$ & 0.591 & 0.538 & 11.098 \\
\hline
\end{tabular}

Source: Field survey 2013.

Note: *** Significant at $1 \%$; ** Significant at 5\%; * Significant at $10 \%$. Values in parentheses are t-ratios

\subsection{Production Elasticity}

The inputs elasticity of production (Table 3 ), shows that farm size, value of land, value of cassava cuttings and labour were $0.010,0.184,-0.230$ and -0.289 respectively. The elasticity of the inputs was inelastic, although that for value of land had more influence when compared to farm size. Therefore policies that will influence land value will greatly influence output of cassava production.

Table 3. Production elasticity

\begin{tabular}{ll}
\hline Variable & Elasticity \\
\hline Farm size & 0.010 \\
Value of land & 0.184 \\
Labour & -0.230 \\
Cassava cuttings & -0.289 \\
\hline
\end{tabular}

Source: Field survey 2013.

\subsection{Profitability Analysis}

The profitability analysis (Table 4), shows that per hectare gross margin was $\$ 9,520.66$. This implies that cassava production was profitable in the study area. The table also shows that total revenue was about 46 percent more than double the cost incurred by the cassava farmers.

Table 4. Profitability analysis

\begin{tabular}{lcccc}
\hline Variables & Mean $(\mathbf{N})$ & Minimum & Maximum & Standard deviation \\
\hline Total revenue & $17,512.6$ & 3015 & 14.317 .21 & 5770.48 \\
Total variable cost & $7,001.94$ & $1,288.33$ & $9,637.66$ & 4187.79 \\
Gross margin/ha & $9,620.66$ & 4.786 .3 & $8,533.8$ & 5660.4 \\
\hline
\end{tabular}

Source: Field survey 2013.

\subsection{Constraints Associated with Cassava Production}

The problems militating against cassava production is presented in table 5. The result shows that high cost of inputs ( 86.25 percent) was the most serious problem encountered by cassava farmers. This was followed by unavailability of land (83.75 percent), lack of extension services (82.5 percent), shortage of capital (81.25 
percent), shortage of labour (76.25 percent), poor crop prices (75 percent), inaccessible markets ( 73.75 percent), while the least problem encountered was lack of implements (70 percent). These problems affected output of cassava production.

Table 5. Constraints to cassava production

\begin{tabular}{lcc}
\hline Constraint & Percentage & Rank \\
\hline High cost of inputs & 86.25 & $1^{\text {st }}$ \\
Unavailability of land & 83.75 & $2^{\text {nd }}$ \\
Lack of extension services & 82.5 & $3^{\text {rd }}$ \\
Shortage of capital & 81.25 & $4^{\text {th }}$ \\
Shortage of labour & 76.25 & $5^{\text {th }}$ \\
Poor crop prices & 75 & $6^{\text {th }}$ \\
Inaccessible markets & 73.75 & $7^{\text {th }}$ \\
Lack of implements & 70 & $8^{\text {th }}$ \\
\hline
\end{tabular}

Source: Field survey 2013.

Note: Total percentage exceeds 100 due to multiple responses.

\section{Conclusion and Recommendations}

This study reveals that output of cassava production was determined by farm size, value of land, age, gender, educational attainment, farming experience, value of cassava cuttings, labour and family size. Whereas farm size, value of land, gender, age, educational attainment and farming experience were variables that had positive influence on cassava output, other variables such as cassava cuttings, labour and family size had negative influence on output. However, value of cassava cuttings, labour, education and experience were found to be statistically significant, implying that these variables exerted greater influence on output of cassava. The production elasticity shows that the inputs were inelastic. The profitability analysis also revealed that cassava production was profitable as total revenue far exceeded the total variable cost incurred by farmers, with a per hectare gross margin of $\$ 9,520.66$.

Constraints to cassava production were identified and showed that high cost of inputs was the most serious problem, while lack of implements constituted the least problem. Therefore, since labour, value of cassava cuttings, education and farmer's experience greatly influenced output of cassava; farmers are advised to redirect labour resource to more productive enterprise as it was found to be unproductive in cassava production. Also policies aimed at encouraging the adoption of improved technology should be vigorously pursued.

Farmers' education and experience are vital for increased productivity; therefore concerted effort must be made towards the implementation of policies that enhances farmers' education.

\section{References}

Abam, O. E. (2009). Analysis of Technical and Economic Efficiencies of Cassava producers in Cross River State, Nigeria: A Stochastic frontier approach. Unpublished M.Sc thesis, Department of Agricultural Economics and Extension, University of Calabar, Nigeria.

Abang, S. O., \& Agom, D. I. (2004). Resource use efficiency of small-holder farmers: The case of cassava producers in Cross River State, Nigeria. Journal of Food, Agriculture and Environment, 2(3\&4) 87-90. htt://dx.doi.org/10.5539/j.fae.v2.3n4.139

Abdullahi, A. (2012). Comparative Economic Analysis of Rice Production by Adopters and Non-Adopters of improved varieties among farmers in Paikoro Local Government Area of Niger State. Nigerian Journal of Basic and Applied Science, 20(2), 146-151. htt://dx.doi.org/10.39231/njbas.2012

Atuanya, P., \& Augie, B. (2014). Breaking down Nigeria rebase USD510billion GDP. Businessday, April 7. Retrieved on August $21^{\text {st }} 2014$ from www.businessdayonline.com

Barry, P. J., Hapkin, J. A., \& Baker, C. B. (1983). Financial Management in Agriculture. Dawille, Illinois: The Interstate Printer and publishers, Inc. 
Effiong, E. O. (2005). Efficiency of Production in selected livestock Enterprise in Akwa Ibom State, Nigeria. Unpublished Ph.D Dissertation, Department of Agricultural Economics, Michael Okpara University of Agriculture, Umudike, Nigeria.

Food and Agriculture Organization (FAO). (2005). Quarterly Bulletin Statistics. FAO Rome, 2(3), 120.

Imoudu, P. B. (1992). Economics of Maize Production and Marketing in Ondo State, Nigeria. Unpublished Ph.D thesis, Department of Agricultural Economics and Extension, FUTA, Akure, Ondo State, Nigeria. In Olujenyo, F. O. (Ed.), The Determinants of Agricultural Production and Profitability in Akoko Land, Ondo State, Nigeria. htt://dx.doi.org/10.3844/jssp.2008.37.41

Mohammed, S. (2011). Economics of Rainfed and Irrigated rice production under upper Benue River Basin Development Authority Scheme, Dadinkowa, Gombe State, Nigeria. Continental J. Agricultural Economics, $5(1), 14-22$.

Mundlak, Y. (2007). Agricultural Productivity and Economic Policies: Concepts and Measurements. OECD Working paper No.75, OECD Development Center. Retrieved from htt://miranda.sourceoecd.org/v1=41726471/cl=20/nw=1/rpsv/cgibin/wppdf?file=5lgsjhvj7g2l.pdf

Nwaru, J. C. (2004). Rural Credit Market and Arable Crop Production in Imo State of Nigeria. Unpublished $\mathrm{Ph} . \mathrm{D}$ Dissertation, Michael Okpara University of Agriculture, Umudike, Nigeria.

Oyinbo, O., Damisa, M. A., \& Ugbabe, O. O. (2011). An assessment of the profitability of smallscale cassava production in Edo State: A guide to policy. Retrieve on September 22, 2014 from http://www.academia.edu/1995184

Zepeda, L. (2001). Agricultural Investment and Productivity in Developing Countries. FAO Economic And Social Development Paper No. 148. $\quad$ Retrieved from http:/www.fao.org/docrep/003/x9447E/x9447e00.HTM.(1)

\section{Copyrights}

Copyright for this article is retained by the author(s), with first publication rights granted to the journal.

This is an open-access article distributed under the terms and conditions of the Creative Commons Attribution license (http://creativecommons.org/licenses/by/3.0/). 